\title{
Gastric Collision Tumor of Adenocarcinoma and MALT Lymphoma: A Rare Coincidence or Proof of $H_{*}$ pylori Incrimination?
}

\author{
Haithem Zaafouri ${ }^{*}$, Anis Hasnaoui ${ }^{1}$, Raja Jouini' ${ }^{2}$, Dhafer Haddad1, Ahmed Bouhafa1, \\ Anis Ben Maamer ${ }^{1}$ \\ ${ }^{1}$ Department of Surgery, Habib Thameur Hospital, Tunis, Tunisia \\ ${ }^{2}$ Department of Histopathology and Cytology, Habib Thameur Hospital, Tunis, Tunisia \\ Email: "zaafouri.haithem@hotmail.fr
}

Received 23 June 2016; accepted 19 August 2016; published 22 August 2016

Copyright (C) 2016 by authors and Scientific Research Publishing Inc.

This work is licensed under the Creative Commons Attribution International License (CC BY). http://creativecommons.org/licenses/by/4.0/

(c) (i) Open Access

\begin{abstract}
Collision tumors of adenocarcinoma and MALT (Mucosa-associated lymphoid tissue) lymphoma are often rare findings of resection specimens of gastric carcinomas. The fact that these two histological lesions are contiguous may suggest a common oncogene. As it is widely known, Helicobacter pylori (H. pylori) plays a leading role in gastric oncogenesis. Could it be responsible for these tumors? As of today, the exact mechanism is still unclear. However, some histological findings may suggest that $H$. pylori promotes the formation of MALT lymphoma which increases the risk of carcinomatous changes. Prognosis of collision tumors is tightly linked to the carcinoma lesion, which is generally poor due to diagnostic delay. Large scale strategies to eradicate $H$. pylori and detect early lesions could reduce the mortality of this disease.
\end{abstract}

\section{Keywords}

Collision Tumor, Gastric, Lymphoma, Adenocarcinoma, Helicobacter pylori

\section{Introduction}

Since the discovery of Helicobacter pylori (H. pylori) in 1982 and the establishment of causative effect between this pathogen and ulcerative disease, researchers tried to incriminate this agent as a leading suspect in gastric malignancies. In fact, some observations of regression of MALT (Mucosa-associated lymphoid tissue) lymphoma with antibiotic treatment for $H$. pylori leaded to the hypothesis of a relationship between them [1]. This was not the case for adenocarcinoma. But, other rare findings of contiguous MALT lymphoma and adenocarcinoma

${ }^{*}$ Corresponding author. 
[2]-[4] raised suspicions of a common origin. In this study, we report a case of a collision tumor of adenocarcinoma and a MALT lymphoma in the stomach that may suggest a common oncogene. If this is true, could it be the infamous $H$. pylori?

\section{Case Report}

A 74-year-old woman presented to our outpatient department with non-radiating epigastric pain of two months' duration, periodic vomiting, loss of appetite, and loss of weight. There were no personal history of fever or gastro-intestinal bleeding and no family history of gastric cancer.

Inspection showed no conjunctival pallor and no abdominal lump. On palpation, epigastric tenderness was noted with no palpable mass. No adenopathy and no hepatosplenomegaly were found and digital rectal examination was normal.

Laboratory blood tests were unrevealing (Hemoglobin level was at $127 \mathrm{~g} / \mathrm{L}$, total leucocyte count was 8200/ml, liver function tests were normal).

Gastroscopy showed a suspicious area of gastric carcinoma in the antrum. Several biopsies were taken, revealing on histological examination an undifferentiated gastric carcinoma.

On CT scan there were no signs of metastatic disease or adenopathy.

After agreement, the patient underwent laparotomy. In the operation field, we discovered ascites and peritoneal carcinomatosis. The gastric tumor was advanced, with transverse mesocolon invasion. A palliative resection of the stomach (Figure 1) and the transverse colon was performed.

The final histological examination showed a collision tumor of an undifferentiated carcinoma and a MALT lymphoma (Figure 2). H. pylori was detected in the specimen.

Post-operative course was uneventful and the patient was referred for chemotherapy.

\section{Discussion}

\subsection{Particularity of Collision Tumors}

Simultaneous coexistence of carcinoma and MALT lymphoma in the stomach is very rare [5]. In two of the largest series, it accounts for $0.098 \%$ [2] and $0.082 \%$ [6] of resection specimens of gastric carcinomas. Preoperative diagnosis of these cases can be challenging since MALT lymphoma can infiltrate the submucosa without altering the mucosa and requires sometimes multiple biopsies or even an endoscopic submucosal dissection [7].

One interesting subtype of these cases is contiguous carcinoma and MALT lymphoma, also known as collision tumor. In this subtype, these two distinct neoplasms develop in juxtaposition to one another, without areas

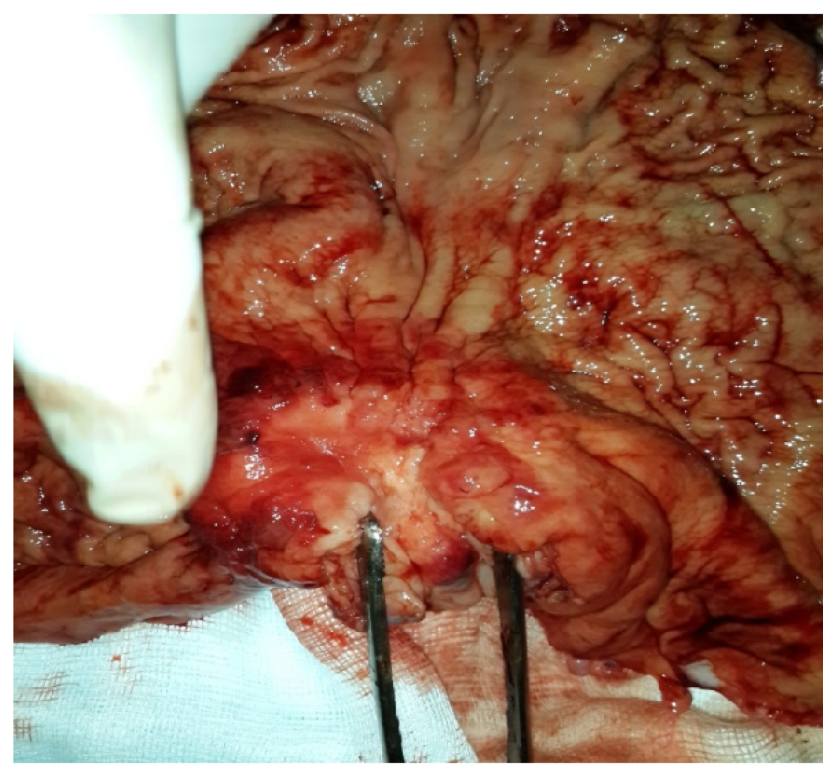

Figure 1. Macroscopic aspect of the tumor in the antrum. 


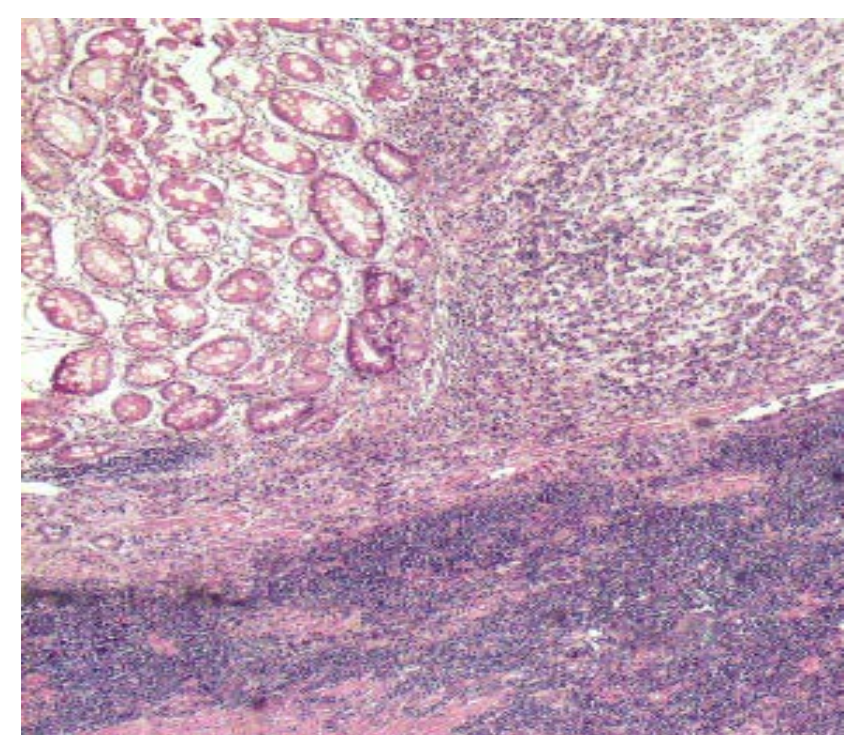

Figure 2. Gastric mucosa is invaded by 2 cellular proliferations: lymphoid and carcinomatous components (HE $\times 40)$.

of intermingling [3]. In the literature, only 26 cases of gastric adenocarcinomas colliding with lymphomas have been reported [8].

An inquirer should ask himself: Is it a mere coincidence of two tumors developing independently at first and then colliding afterwards? Or is it a common oncogene that is responsible for the genesis of the two tumors at the same time? Or maybe that one of the tumors promotes the other?

\subsection{Suggested Role of $H$. pylori in Collision Tumors}

It is widely admitted that $H$. pylori is incriminated in gastric oncogenesis in the animal model [9], as it satisfies the components of Koch's postulates for determining the causative effect between a pathogen and a disease. In humans, the story is more intricate, as these components are not completely fulfilled. In addition to bacterial virulence factors (such as the cytotoxin associated gene A), host genetics, nutrition and environmental factors got their part of the action [10] [11].

As of today, the precise mechanism of gastric collision tumors is still unclear. One fact that we are sure of is that $H$. pylori infection is present in the majority of the cases [2]. This microbe may provoke a lymphocytic gastritis with CD8 T cells infiltration that may promote B cell proliferation, ultimately giving birth to the MALT lymphoma [12]. Many authors think that MALT lymphoma occurs before carcinogenesis and maybe increases the risk of it, as would suggest the smaller size and less wall infiltration of carcinoma in collision tumors in the literature [3] [13] [14], and in our case as well. The main motor for these carcinomatous changes would be the chronic inflammation of the mucosa as suggested by some studies [3] [15].

\subsection{Prognosis}

The lack of data on patient's survival or postoperative therapy, does not allow us to assess the prognosis of collision tumors. Some authors suggest that it is primarily related to the carcinoma prognosis as MALT lymphoma could regress after $H$. pylori eradication therapy [2]. This leads us to the conclusion that prevention and early detection of these lesions could enhance outcomes of this disease.

\section{Conclusion}

Pathogeny of gastric malignancies is intricate and more studies need to be conducted in order to apprehend all of its secrets. H. pylori plays a leading role in this matter. Therefore, until we unveil the full enigma of this disease, prevention against this pathogen is still a string of hope to significantly reduce mortality of one of the major cancers. 


\section{References}

[1] Wotherspoon, A.C., Doglioni, C., Diss, T.C., et al. (1993) Regression of Primary Low-Grade B-Cell Gastric Lymphoma of Mucosa-Associated Lymphoid Tissue Type after Eradication of Helicobacter Pylori. Lancet, 342, 575-577. http://dx.doi.org/10.1016/0140-6736(93)91409-F

[2] Nakamura, S., Aoyagi, K., Iwanaga, S., et al. (1997) Synchronous and Metachronous Primary Gastric Lymphoma and Adenocarcinoma: A Clinicopathological Study of 12 Patients. Cancer, 79, 1077-1085. http://dx.doi.org/10.1002/(SICI)1097-0142(19970315)79:6<1077::AID-CNCR4>3.0.CO;2-D

[3] Goteri, G., Ranaldi, R., Rezai, B., Baccarini, M.G. and Bearzi, I. (1997) Synchronous Mucosa-Associated Lymphoid Tissue Lymphoma and Adenocarcinoma of the Stomach. The American Journal of Surgical Pathology, 21, 505-509. http://dx.doi.org/10.1097/00000478-199705000-00001

[4] George, S.A. and Junaid, T.A. (2014) Gastric Marginal Zone Lymphoma of Mucosa-Associated Lymphoid Tissue and Signet Ring Cell Carcinoma, Synchronous Collision Tumour of the Stomach: A Case Report. Medical Principles and Practice, 23, 377-379. http://dx.doi.org/10.1159/000356180

[5] Nishino, N., Konno, H., Baba, S., et al. (1996) Synchronous Lymphoma and Adenocarcinoma Occurring as a Collision Tumor in the Stomach: Report of a Case. Surgery Today, 26, 508-512. http://dx.doi.org/10.1007/BF00311557

[6] Noda, T., Akashi, H., Matsueda, S., et al. (1989) Collision of Malignant Lymphoma and Multiple Early Adenocarcinomas of the Stomach. Archives of Pathology \& Laboratory Medicine, 113, 419-422.

[7] Tomizawaa, Y., Sekib, M. and Moric, M. (2012) Unusual Presentation of Localized Gastric Mucosa-Associated Lymphoid Tissue Lymphoma Mimicking Poorly Differentiated Gastric Adenocarcinoma. Gastroenterology, 6, 47-51.

[8] Michalinos, A., Constantinidou, A. and Kontos, M. (2015) Gastric Collision Tumors: An Insight into Their Origin and Clinical Significance. Gastroenterology Research and Practice, 2015, Article ID: 314158. http://dx.doi.org/10.1155/2015/314158

[9] Kodama, M., Murakami, K., Sato, R., Okimoto, T., Nishizono, A. and Fujioka, T. (2005) Helicobacter Pylori-Infected Animal Models Are Extremely Suitable for the Investigation of Gastric Carcinogenesis. World Journal of Gastroenterology, 11, 7063-7071. http://dx.doi.org/10.3748/wjg.v11.i45.7063

[10] Mbulaiteye, S.M., Hisada, M. and El-Omar, E.M. (2010) Helicobacter Pylori Associated Global Gastric Cancer Burden. Frontiers in Bioscience, 14, 1490-1504.

[11] Zucca, E., Bertoni, F., Roggero, E. and Cavalli, F. (2000) The Gastric Marginal Zone B-Cell Lymphoma of MALT Type. Blood, 96, 409-410.

[12] Griffiths, A.P., Wyatt, J., Jack, A.S. and Dixon, M.F. (1994) Lymphocytic Gastritis, Gastric Adenocarcinoma, and Primary Gastric Lymphoma. Journal of Clinical Pathology, 47, 1123-1124. http://dx.doi.org/10.1136/jcp.47.12.1123

[13] Bu, W.J., Pei, H.H., Li, L. and Li, Z.F. (2014) Synchronous Adenocarcinoma and Mucosal-Associated Lymphoid Tissue Lymphoma of the Stomach. Chinese Medical Journal, 127, 1388-1389.

[14] Hamaloglu, E., Topaloglu, S., Ozdemir, A. and Ozenc, A. (2006) Synchronous and Metachronous Occurrence of Gastric Adenocarcinoma and Gastric Lymphoma: A Review of the Literature. World Journal of Gastroenterology, 12, 3564-3574. http://dx.doi.org/10.3748/wjg.v12.i22.3564

[15] Planker, M., Fischer, J.T., Peters, U. and Borchard, F. (1984) Synchronous Double Primary Malignant Lymphoma of Low Grade Malignancy and Early Cancer (Collision Tumor) of the Stomach. Hepatogastroenterology, 31, 144-148. 


\section{Submit or recommend next manuscript to SCIRP and we will provide best service for you:}

Accepting pre-submission inquiries through Email, Facebook, LinkedIn, Twitter, etc.

A wide selection of journals (inclusive of 9 subjects, more than 200 journals)

Providing 24-hour high-quality service

User-friendly online submission system

Fair and swift peer-review system

Efficient typesetting and proofreading procedure

Display of the result of downloads and visits, as well as the number of cited articles

Maximum dissemination of your research work

Submit your manuscript at: http://papersubmission.scirp.org/ 